\title{
An application of fuzzy TOPSIS for ranking strategies
}

\author{
Shadi Ansari $^{\mathrm{a}^{*}}$, Mohammad Ali Afshar Kazemi ${ }^{\mathrm{b}}$ and Abbas Toloie Eshlaghy
}

${ }^{a}$ Masters Student, Department of Executive Management, Science and Research Branch, Islamic Azad University, Saveh, Iran

${ }^{b}$ Associate Professor, Department of Industrial Management, Islamic Azad University, Tehran Central Branch, Tehran, Iran

${ }^{c}$ Full Professor, Department of Industrial Management, Science and Research Branch, Tehran, Iran

\section{H R O N I C L E}

\section{Article history:}

Received July 28, 2013

Received in revised format

20 November 2013

Accepted 14 January 2014

Available online

February 242014

Keywords:

Strategic planning

Fuzzy TOPSIS

AHP

Kara Sazeh Matin

\section{A B S T R A C T}

\section{Introduction}

Strategy plays an essential role for the success of organizations; it helps determine strength and weakness as well as opportunities and threats. During the past few years, there have been different methods developed for strategy planning. Celik et al. (2012) proposed a hybrid method on ensuring the competitiveness requirements for major Turkish container ports by utilizing fuzzy axiomatic design (FAD) and fuzzy technique for order performance by similarity to ideal solution (TOPSIS) methods to manage strategic decision-making with incomplete data. The outcomes of the quantitative techniques were utilized as data input for SWOT analysis, which provide additional contributions to detect the development strategies on container ports. They claimed that the strategies on Turkish container ports could be originally recommended as guidelines for Turkish maritime industry.

*Corresponding author. Tel: +989128705512

E-mail addresses: shadi.ansari@yahoo.com (Sh. Ansari) 
Paksoy et al. (2012) developed the organization strategy of distribution channel management based on fuzzy analytic hierarchy process (FAHP) (Zadeh, 1965) and hierarchical fuzzy TOPSIS (HFTOPSIS) for an edible-vegetable oils manufacturer firm operating in Turkey. The firm distributed its products all over the country and because of the complex structure of the distribution network, the firm wished to decide the organization strategy to manage the distribution channels. They applied FAHP and HFTOPSIS select among the five organization strategy techniques for distribution channel management of vegetable oil manufacturer.

Bas (2013) developed an integrated framework for analysis of electricity supply chain using an integrated SWOT-fuzzy TOPSIS methodology combined with AHP (Saaty, 1980; 1994). Patil and Kant (2014) used a fuzzy AHP-TOPSIS framework for ranking the solutions of Knowledge Management adoption in Supply Chain to overcome its barriers. Kim et al. (2013) prioritized the best sites for treated wastewater instream use in an urban watershed using fuzzy TOPSIS. Büyüközkan and Çifçi (2012) presented a combined fuzzy AHP and fuzzy TOPSIS based strategic analysis of electronic service quality in healthcare industry.

Taylan et al. (2014) proposed some analytic tools to make an assessment on the construction projects and their overall risks under incomplete and uncertain situations. The proposed hybrid methodologies were started with a survey for collection of the necessary data. The relative importance index (RII) method was used to rank the project risks based on the data collected. The construction projects were then categorized by fuzzy AHP (FAHP) and fuzzy TOPSIS methods where FAHP was applied to generate favorable weights for fuzzy linguistic variable of construction projects overall risk. The fuzzy TOPSIS method has become popular for solving group decision making problems under the fuzzy environment. They attempted to incorporate necessary qualitative attributes in performance analysis of construction projects and transformed the qualitative data into equivalent quantitative figures. They studied 30 construction projects in terms of five main criteria that are the time, cost, quality, safety and environment sustainability. They reported that these novel methodologies were capable of assessing the overall risks of construction projects, selected the project with minimum risk with the contribution of relative importance index.

Kannan et al. (2014) applied Fuzzy TOPSIS to select green suppliers for a Brazilian electronics firm based on the criteria of green supply chain management (GSCM) practices from a set of 12 available suppliers. They applied a fuzzy TOPSIS approach to rank the suppliers, and the results of the proposed framework were compared with the ranks achieved by both the geometric mean and the graded mean techniques of fuzzy TOPSIS method. They also used a Spearman rank correlation coefficient to determine the statistical difference between the ranks obtained by the three techniques. Finally, a sensitivity analysis has been executed to study the effect of the preferences given by the decision makers for the chosen GSCM practices on the selection of green suppliers. They reported that the four dominant criteria were "Commitment of senior management to GSCM; Product designs that reduce, reuse, recycle, or reclaim materials, components, or energy; Compliance with legal environmental requirements and auditing programs; and Product designs that avoid or reduce toxic or hazardous material use".

Bai et al. (2014) introduced a multi-method multiple criteria technique for assessing the performance of different firms. Performance analysis normally includes both strategic and operational performance, as well as financial and other less tangible factors. They introduced the application of Fuzzy C-Means and TOPSIS for organizational performance evaluation purposes based on balanced scorecard accounting. They reported that economic performance evaluation could not be the best predictor of overall viability of some organizations, especially e-commerce based organizations. 


\section{The proposed study}

\subsection{The case study}

The proposed study of this paper has been implemented in one of Middle East construction firm named Kara Sazeh Matin (KSM group). KSM GROUP is a private firm with the relevant affiliated factories in the construction industry and private investment (IPP). Since 2000, the firm has finished about 28 projects in different fields of construction. In addition, the firm offers 16 different products and services to its customers as follows:

1. Building Industry,

2. Road transportation services,

3. Tourism industry,

4. Domestic and Foreign Commercial Service.

\subsection{The proposed fuzzy TOPSIS}

This paper presents some analytic tools to make an assessment on the construction projects and their overall risks under incomplete and uncertain circumstances. The proposed hybrid methodologie begins with a survey for collection of the necessary data. Different existing projects are then categorized by FAHP (Chang, 1996) and fuzzy TOPSIS methods where FAHP is implemented to generate favorable weights for fuzzy linguistic variable of construction projects overall risk (Chen, 2000). The fuzzy TOPSIS method has become popular for solving group decision making problems under the fuzzy environment (Jannatifar et al., 2012; Nazari et al., 2012). The study attempts to incorporate necessary qualitative attributes in performance analysis of construction projects and transforms the qualitative data into equivalent quantitative figures. They studied different projects in terms of four main criteria that are improvement in buy/sell system and marketing planning, financial and cost management, human resources management and technology management. Table 1 shows details of eleven strategies.

\section{Table 1}

The summary of different strategies

\begin{tabular}{|c|c|c|c|}
\hline Strategy & Description & Strategy & Description \\
\hline S1 & $\begin{array}{l}\text { Production of UPVC and distribution of different } \\
\text { components such as windows, doors, etc. }\end{array}$ & S7 & $\begin{array}{l}\text { Development of steel deck roof producing as a } \\
\text { modular approach }\end{array}$ \\
\hline S2 & Increase in the number of transportation agencies & S8 & $\begin{array}{l}\text { Increase in sales marketing advertising materials } \\
\text { such as sand projects in southern Tehran }\end{array}$ \\
\hline S3 & $\begin{array}{l}\text { Providing consultation activities in the area of strength of } \\
\text { materials nationwide }\end{array}$ & S9 & $\begin{array}{l}\text { Increasing engineering services including design } \\
\text { and supervision of the country }\end{array}$ \\
\hline S4 & $\begin{array}{l}\text { Export of construction stones to European and Asian } \\
\text { countries }\end{array}$ & S10 & $\begin{array}{l}\text { Establishment of a management information system } \\
\text { and R \& D }\end{array}$ \\
\hline S5 & $\begin{array}{l}\text { Empowering volleyball team to participate in } \\
\text { international leagues }\end{array}$ & S11 & Selling some inefficient units \\
\hline S6 & Purchasing top grade firm in the area of construction & S12 & Closing some unprofitable projects \\
\hline
\end{tabular}

In addition, there are four criteria, where we compare the alternatives and they are summarized in Table 2 as follows,

\section{Table 2}

The summary of four criteria

\begin{tabular}{lll}
\hline Criteria & Description & Relative importance \\
\hline 1 & Improvement in buy/sell system and marketing planning & Very much \\
2 & Financial and cost management & Average \\
3 & Human resources management & More than average \\
4 & Technology management & High \\
\hline
\end{tabular}


The study gathers the data in terms of rectangular data and Table 3 shows details of the survey.

Table 3

The summary of the data in terms of Rectangular fuzzy numbers for different criteria and strategies

\begin{tabular}{ccccc}
\hline w & $(8,9,10,10)$ & $(4,5,5,6)$ & $(5,6,7,8)$ & $(7,8,8,9)$ \\
\hline & $\mathrm{C} 1$ & $\mathrm{C} 2$ & $\mathrm{C} 3$ & $\mathrm{C} 4$ \\
\hline $\mathrm{S}_{1}$ & $(8,9,10,10)$ & $(1,2,2,3)$ & $(2,3,4,5)$ & $(4,5,5,6)$ \\
$\mathrm{S}_{2}$ & $(8,9,10,10)$ & $(5,6,7,8)$ & $(4,5,5,6)$ & $(4,5,5,6)$ \\
$\mathrm{S}_{3}$ & $(4,5,5,6)$ & $(5,6,7,8)$ & $(7,8,8,9)$ & $(8,9,10,10)$ \\
$\mathrm{S}_{4}$ & $(8,9,10,10)$ & $(7,8,8,9)$ & $(5,5,5,6)$ & $(5,6,7,8)$ \\
$\mathrm{S}_{5}$ & $(4,5,5,6)$ & $(7,8,8,9)$ & $(2,10,10)$ & $(8,9,1,7)$ \\
$\mathrm{S}_{6}$ & $(8,9,10,10)$ & $(7,8,8,9)$ & $(2,3,4,5)$ & $(8,9,10,10)$ \\
$\mathrm{S}_{7}$ & $(5,6,7,8)$ & $(8,9,10,10)$ & $(1,2,2,3)$ & $(5,6,7,8)$ \\
$\mathrm{S}_{8}$ & $(8,9,10,10)$ & $(4,5,5,6)$ & $(8,9,10,10)$ & $(8,9,10,10)$ \\
$\mathrm{S}_{9}$ & $(5,6,7,8)$ & $(2,3,4,5)$ & $(7,8,8,9)$ & $(8,9,10,10)$ \\
$\mathrm{S}_{10}$ & $(4,5,5,6)$ & $(7,8,8,9)$ & $(1,2,2,3)$ & $(2,3,4,5)$ \\
$\mathrm{S}_{11}$ & $(4,5,5,6)$ & $(8,9,10,10)$ & $(4,5,5,6)$ & $(5,6,7,8)$ \\
$\mathrm{S}_{12}$ & $(7,8,8,9)$ & $(8,9,10,10)$ & & \\
\hline
\end{tabular}

\section{The results}

In this section, we present details of the implementation of fuzzy TOPSIS. Table 4 and Table 5 show the results of distances from the ideal positive and negative factors.

Table 4

The summary of the results of the survey for the ideal positive factors

\begin{tabular}{ccccccc}
\hline & $\mathrm{C}_{1}$ & $\mathrm{C}_{2}$ & $\mathrm{C}_{3}$ & $\mathrm{C}_{4}$ & $\mathrm{SUM}$ & $\mathrm{D} \mathrm{i}+$ \\
\hline $\mathrm{S}_{1}$ & 0.2035 & 0.4974 & 0.5711 & 0.5034 & 1.7754 & $\mathrm{D} 1+$ \\
$\mathrm{S}_{2}$ & 0.2035 & 0.2858 & 0.4782 & 0.5034 & 1.4709 & $\mathrm{D} 2+$ \\
$\mathrm{S}_{3}$ & 0.5429 & 0.2858 & 0.3036 & 0.1987 & 1.33 & $\mathrm{D}+$ \\
$\mathrm{S}_{4}$ & 0.2035 & 0.2156 & 0.4782 & 0.3958 & 1.2931 & $\mathrm{D}++$ \\
$\mathrm{S}_{5}$ & 0.5419 & 0.2156 & 0.2437 & 0.3958 & 1.397 & $\mathrm{D} 5+$ \\
$\mathrm{S}_{6}$ & 0.2035 & 0.2156 & 0.5711 & 0.1987 & 1.1889 & $\mathrm{D} 6+$ \\
$\mathrm{S}_{7}$ & 0.4188 & 0.1665 & 0.5711 & 0.1987 & 1.3551 & $\mathrm{D} 7+$ \\
$\mathrm{S}_{8}$ & 0.2035 & 0.3522 & 0.6654 & 0.3958 & 1.6168 & $\mathrm{D} 8+$ \\
$\mathrm{S}_{9}$ & 0.4188 & 0.4251 & 0.2437 & 0.1987 & 1.2863 & $\mathrm{D} 9+$ \\
$\mathrm{S}_{10}$ & 0.5419 & 0.2156 & 0.3036 & 0.1987 & 1.2598 & $\mathrm{D} 10+$ \\
$\mathrm{S}_{11}$ & 0.5419 & 0.1665 & 0.6654 & 0.6229 & 1.9967 & $\mathrm{D} 11+$ \\
$\mathrm{S}_{12}$ & 0.2837 & 0.1665 & 0.4782 & 0.3958 & 1.3242 & $\mathrm{D} 12+$ \\
\hline
\end{tabular}

Table 5

The summary of the results of the survey for the ideal negative factors

\begin{tabular}{|c|c|c|c|c|c|c|}
\hline & $\mathrm{C}_{4}$ & $\mathrm{C}_{3}$ & $\mathrm{C}_{2}$ & $\mathrm{C}_{1}$ & SUM & Di- \\
\hline $\mathrm{S}_{1}$ & 0.5628 & 0.0818 & 0.2206 & 0.4804 & 1.3456 & D1- \\
\hline $\mathrm{S}_{2}$ & 0.5628 & 0.3094 & 0.2999 & 0.4804 & 1.6525 & D2- \\
\hline $\mathrm{S}_{3}$ & 0.1786 & 0.3094 & 0.4959 & 0.6176 & 1.6015 & D3- \\
\hline $\mathrm{S}_{4}$ & 0.5628 & 0.3574 & 0.2999 & 0.4100 & 1.6301 & D4- \\
\hline $\mathrm{S}_{5}$ & 0.1786 & 0.3574 & 0.5804 & 0.4100 & 1.5264 & D5- \\
\hline $\mathrm{S}_{6}$ & 0.5628 & 0.3574 & 0.2206 & 0.6176 & 1.7584 & D6- \\
\hline $\mathrm{S}_{7}$ & 0.1036 & 0.4657 & 0.2206 & 0.6176 & 1.4075 & D7- \\
\hline $\mathrm{S}_{8}$ & 0.5628 & 0.4997 & 0.1108 & 0.4100 & 1.5833 & D8- \\
\hline $\mathrm{S}_{9}$ & 0.1036 & 0.1637 & 0.5804 & 0.6176 & 1.4653 & D9- \\
\hline $\mathrm{S}_{10}$ & 0.1786 & 0.3574 & 0.4959 & 0.6176 & 1.6495 & D10- \\
\hline $\mathrm{S}_{11}$ & 0.1786 & 0.4657 & 0.1108 & 0.1860 & 0.9411 & D11- \\
\hline$S_{12}$ & 0.4428 & 0.4657 & 0.2999 & 0.4100 & 1.6184 & D12- \\
\hline
\end{tabular}

Finally, Table 6 shows details of the results of the implementation of fuzzy TOPSIS.

Table 6

The summary of ranking based on fuzzy TOPSIS

\begin{tabular}{lcccccccccccc}
\hline & $\mathrm{S}_{1}$ & $\mathrm{~S}_{2}$ & $\mathrm{~S}_{3}$ & $\mathrm{~S}_{4}$ & $\mathrm{~S}_{5}$ & $\mathrm{~S}_{6}$ & $\mathrm{~S}_{7}$ & $\mathrm{~S}_{8}$ & $\mathrm{~S}_{9}$ & $\mathrm{~S}_{10}$ & $\mathrm{~S}_{11}$ & $\mathrm{~S}_{12}$ \\
\hline Closeness & 0.4311 & 0.5290 & 0.5463 & 0.5576 & 0.5221 & 0.5966 & 0.5094 & 0.4947 & 0.5325 & 0.5669 & 0.3203 & 0.5499 \\
Rank & 11 & 7 & 5 & 3 & 8 & 1 & 9 & 10 & 6 & 2 & 12 & 4 \\
\hline
\end{tabular}




\section{Discussion and conclusion}

According to the results of Table 6, sixth strategy is number one priority. In other words, the experts believe that purchasing top grade firm in the area of construction is the most important and strategic effort to do in order to make business development. Increase in the number of transportation agencies is the second most important strategies that the firm must consider in order to become leader in its field. Export of construction stones to European and Asian countries is considered as the third important strategy that this firm could do in order to develop its operations. The experts believe that the firm must take immediate action to close its non-value added units as quickly as possible as part of their efforts in reducing the unnecessary expenses. According to our survey empowering volleyball team to participate in international leagues could help build a good exposure in market and it is considered as an efficient method of advertisement.

\section{Acknowledgement}

The authors would like to thank the anonymous referees for constructive comments on earlier version of this paper.

\section{References}

Bai, C., Dhavale, D., \& Sarkis, J. (2014). Integrating Fuzzy C-Means and TOPSIS for performance evaluation: An application and comparative analysis. Expert Systems with Applications, 41(9), 4186-4196.

Bas, E. (2013). The integrated framework for analysis of electricity supply chain using an integrated SWOT-fuzzy TOPSIS methodology combined with AHP: The case of Turkey. International Journal of Electrical Power \& Energy Systems, 44(1), 897-907.

Büyüközkan, G., \& Çifçi, G. (2012). A combined fuzzy AHP and fuzzy TOPSIS based strategic analysis of electronic service quality in healthcare industry. Expert Systems with Applications, 39(3), 2341-2354.

Celik, M., Cebi, S., Kahraman, C., \& Er, I. D. (2009). Application of axiomatic design and TOPSIS methodologies under fuzzy environment for proposing competitive strategies on Turkish container ports in maritime transportation network. Expert Systems with Applications, 36(3), 4541-4557.

Chang, D. Y. (1996). Applications of the extent analysis method on fuzzy AHP.European journal of operational research, 95(3), 649-655.

Chen, C.T. (2000). Extension of the TOPSIS for group decision- making under fuzzy environment. Fuzzy Sets and Systems, 114, 1-9.

Jannatifar, H., KazemKeshvar Shahi, M., \& Siahkali Moradi, J. (2012). Assessing intellectual capital management by fuzzy TOPSIS. Management Science Letters, 2(6), 1991-2000.

Kannan, D., Jabbour, A. B. L. D. S., \& Jabbour, C. J. C. (2014). Selecting green suppliers based on GSCM practices: Using fuzzy TOPSIS applied to a Brazilian electronics company. European Journal of Operational Research, 233(2), 432-447.

Kim, Y., Chung, E. S., Jun, S. M., \& Kim, S. U. (2013). Prioritizing the best sites for treated wastewater instream use in an urban watershed using fuzzy TOPSIS. Resources, Conservation and Recycling, 73, 23-32.

Nazari, I., Vakil Alroaia, Y., \& Bahraminasab, S. (2012). An application of multiple criteria decisionmaking techniques for ranking different national Iranian oil refining and distribution companies. Management Science Letters, 2(7), 2341-2346.

Paksoy, T., Pehlivan, N. Y., \& Kahraman, C. (2012). Organizational strategy development in distribution channel management using fuzzy AHP and hierarchical fuzzy TOPSIS. Expert Systems with Applications, 39(3), 2822-2841. 
Patil, S. K., \& Kant, R. (2014). A fuzzy AHP-TOPSIS framework for ranking the solutions of Knowledge Management adoption in Supply Chain to overcome its barriers. Expert Systems with Applications, 41(2), 679-693.

Saaty, T.L. (1980). The Analytic Hierarchy Process. McGraw Hill Publications.

Saaty, T.L. (1994). How to make a decision: The analytic hierarchy process. Interfaces, 24(6), 19-43.

Taylan, O., Bafail, A. O., Abdulaal, R., \& Kabli, M. R. (2014). Construction projects Selection and risk assessment by Fuzzy AHP and Fuzzy TOPSIS methodologies. Applied Soft Computing, 17, 105-116.

Zadeh, L.A. (1965). Fuzzy sets. Information and Control, 8(3), 338-353. 